\title{
Ślady idei miasta ogrodu na przykładzie Wożuczyn-Cukrowni
}

\author{
Kamila Lucyna Boguszewska \\ k.boguszewska@pollub.pl \\ Wydziat Budownictwa i Architektury, Politechnika Lubelska
}

\begin{abstract}
Streszczenie: Na początku wieku XX idea miasta ogrodu stworzona przez Ebenezera Howarda (1898) uzyskała rangę nurtu międzynarodowego nie tylko w wymiarze urbanistycznym, ale także i społecznym.

Na grunt Polski pomysł tego typu planowania miast, osiedli i osad został przeszczepiony już w roku 1908, kiedy to po raz pierwszy W. Dobrzyński zapoznał się z założeniami miast ogrodów przedstawionych podczas Międzynarodowego Kongresu Higieny i Demografii w Berlinie.

Na fali popularności idei Howarda w Warszawie i okolicach zaczęły zawiązywać się poszczególne stowarzyszenia miasto ogród: Młociny (1913), Sokolniki (1931), Podkowa Leśna (1933), czy Okęcie (1929). Na tym tle nie dziwi fakt, że osada Wożuczyn projektowana na początku XX wieku przez warszawskiego architekta Tadeusza Zielińskiego utrzymana została według głównych zasad kształtowania miast ogrodów.

Celem artykułu jest przedstawienie stanu zachowania założenia ogrodowego w tej osadzie w świetle zachowanej dokumentacji archiwalnej i przekształceń jakim Wożuczyn-Cukrownia podlegał na przestrzeni ostatnich stu lat.
\end{abstract}

Słowa kluczowe: Miasto ogród, Tadeusz Zieliński, Wożuczyn-Cukrownia.

\section{Wstęp}

Idea miasta ogrodu miała być odpowiedzią na problem rozrastających się przedmieść wielkich miast przełomu XIX i XX wieku oraz jakości kształtowania zabudowy mieszkaniowej. Jej twórcą był angielski planista Ebenezer Howard.

Według niego idealne osiedle mieszkaniowe, pełniące funkcje satelitarną do dużego miasta, miało być z zasady samowystarczalne i przewidziane na maksymalną liczbę 32000 osób. Koncepcja E. Howarda obejmował zagospodarowanie terenu o powierzchni około 400 ha zaś zakładana intensywność miała wynosić od 175 do 200 osób na jeden hektar. Tereny mieszkaniowe miały graniczyć z obszarami przemysłowymi, rolniczymi i obszarami zieleni'.

Miasto ogród posiadało układ centryczny z promieniście odchodzącymi zhierarchizowanymi alejami. W samym centrum założenia zaprojektowany był teren zielony - ogród wokół którego rozplanowane były najważniejsze budynki użyteczności publicznej. Ważnym elementem całego układu była komunikacja w postaci linii kolejowej umieszczonej stycznie do całego układu. Budynki mieszkalne miały formę wolnostojących willi w ogrodzie ${ }^{2}$ (Ryc. 1). 
Pierwszą realizacją tego pomysłu było miasteczko Letchworth (projekt B. Parkera i R. Unwina), którego budowę rozpoczęto w 1904 roku, następnym zaś Wewlyn (1919) w Wielkiej Brytanii ${ }^{3}$. W tych realizacjach zmniejszona została jednak znacznie intensywność zaludnienia przyjęto bowiem liczbę około 120 osób na jeden hektar ${ }^{4}$.

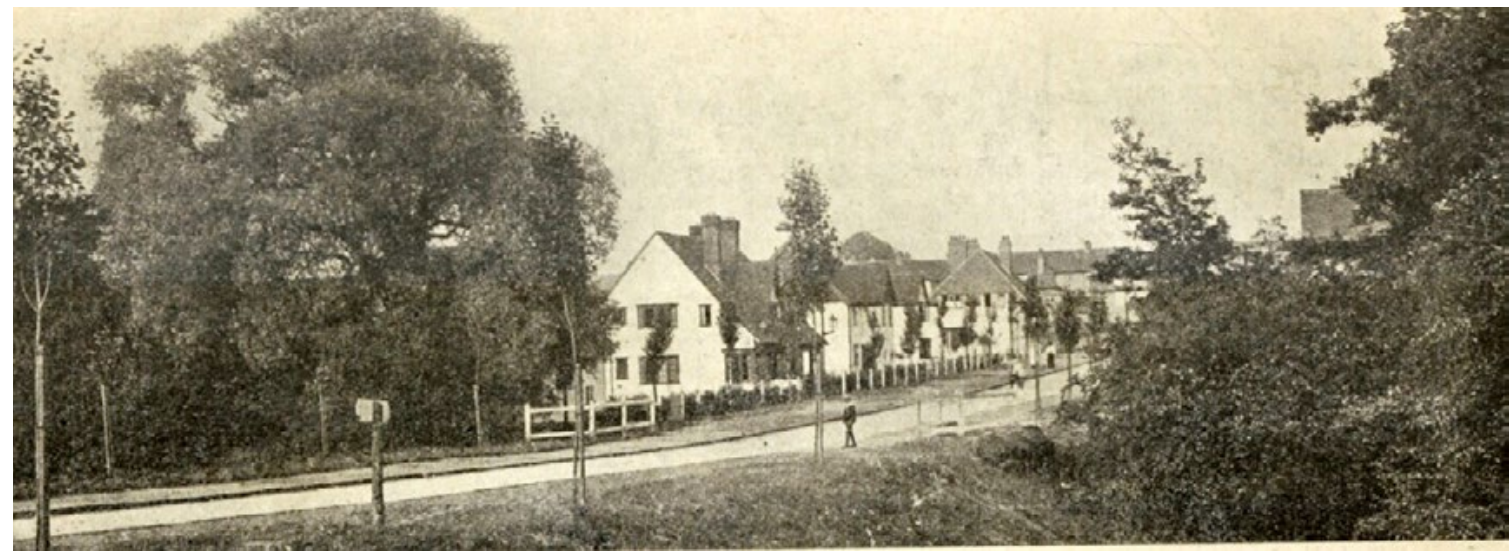

Ryc. 1. Letchworth - zabudowa mieszkaniowa, za: W. Dobrzyński, Istota i rozwój idei Howarda Miasto Ogród, Warszawa, druk Rubieszewskiego i Wrotnowskiego, 1917, ilustracja 7.

Letchworth - housing estate, (W. Dobrzyński, Istota i rozwój idei Howarda Miasto Ogród, Warszawa, druk Rubieszewskiego i Wrotnowskiego, 1917, picture 7).

Koncepcja miasta ogrodu w szybkim czasie zyskała bardzo dużą popularność stając się ruchem międzynarodowym nie tylko planistycznym, ale także i społecznym. Po raz pierwszy pod uwagę brany był czynnik ekonomiczny (własność na zasadzie spółdzielni), zaś projektowanym terenom zieleni przypisano ważną rolę elementu miastotwórczego na dużą skalę ${ }^{5}$.

Idea Howarda (1898) i jej późniejsze realizacje nie były obce w Królestwie Polskim. Na początku wieku XX. swą popularność zawdzięczały działalności doktora Władysława Dobrzyńskiego, propagatora i zwolennika tego nurtu oraz autora licznych publikacji opisujących podstawowe założenia miast ogrodów, między innymi: Zdrowie publiczne a idea miast ogrodów (1911), Postępy idei miast ogrodów w Anglii i u nas (1914), Istota i rozwój idei Howarda miasto ogród (1917).

Na grunt Polski pomysł tego typu planowania miast, osiedli i osad został przeszczepiony już w roku 1908, kiedy to po raz pierwszy W. Dobrzyński zapoznał się z założeniami miast ogrodów przedstawionych podczas Międzynarodowego Kongresu Higieny i Demografii w Berlinie. Unaoczniło to problematykę chaotycznego projektowania osiedli mieszkaniowych w ówczesnym Królestwie Polskim i stało się przyczynkiem do powstania Delegacyi Warszawskiego Towarzystwa Higienicznego do spraw miast ogrodów (1909), której głównym założeniem było propagowanie idei Howarda w formie stowarzyszeń i kooperatyw, popularyzacja idei poprzez naukowe wyjazdy do Niemiec i Anglii oraz organizowanie wystaw w tym Wystawy miast ogrodów w Warszawie.

Na potrzeby pierwszej wystawy, zorganizowanej w roku 1910, sprowadzono dokumentacje architektoniczne oraz przykładowe wzorcowe rozwiązania osiedli ogrodów z Niemiec, Francji i Włoch. Polska przedstawiła natomiast realizacje letnisk z Konstancina i Skolimowa, ogródków robotniczych, letnisk dla dzieci oraz przykłady budownictwa mieszkaniowego z Żyrardowa wraz z projektami parków miejskich Warszawy autorstwa między innymi F. Szaniora i W. Kronenberga ${ }^{6}$.

Już w pierwszym dwudziestoleciu XX wieku powstawać zaczęły śmiałe plany, a następnie realizacje założeń urbanistycznych osiedli ogrodów: w Niemczech Sępolno - obecna dzielnica Wrocławia (1919-1935, projekt

3 E. Przesmycka, Idea osiedli mieszkaniowych w XX wieku [w:] Stalowa Wola europejskie miasto modernistyczne, Muzeum Regionalne w Stalowej Woli, Stalowa Wola, 2014, s. 12.

4 A. Bohm, Planowanie przestrzenne dla ...., op. cit. , s. 50.

5 Ibid., s.127.

6 W. Dobrzański, Krótki zarys prac delegacyi do sprawy miast ogrodów przy Warszawskim Towarzystwie Higienicznym ze sprawozdaniem z wystawy miast ogrodów, Warszawa 1912, Druk synów. S, Niemiry, s. 4-7. 
Paula Heima, Hermanna Wahlicha i Alberta Kemptera) czy Giszowiec - obecna dzielnica Katowic (1907-1910 projekt Georga i Emila Zillmanna).

Na fali popularności w Warszawie i okolicach zaczęły zawiązywać się poszczególne stowarzyszenia miasto ogród: Młociny (1913), Sokolniki (1931), Podkowa Leśna (1933), czy Okęcie (1929) ${ }^{7}$ itd.

W roku 1912 w Królestwie Polskim zaprezentowano zwycięską koncepcję urbanistyczną miasta ogrodu Ząbki pod Warszawą autorstwa T. Tołwińskiego, która miała powstać w majątku Hrabiego Ronikiera - architekta wykształconego w Wiedniu i właściciela dwóch cegielni.

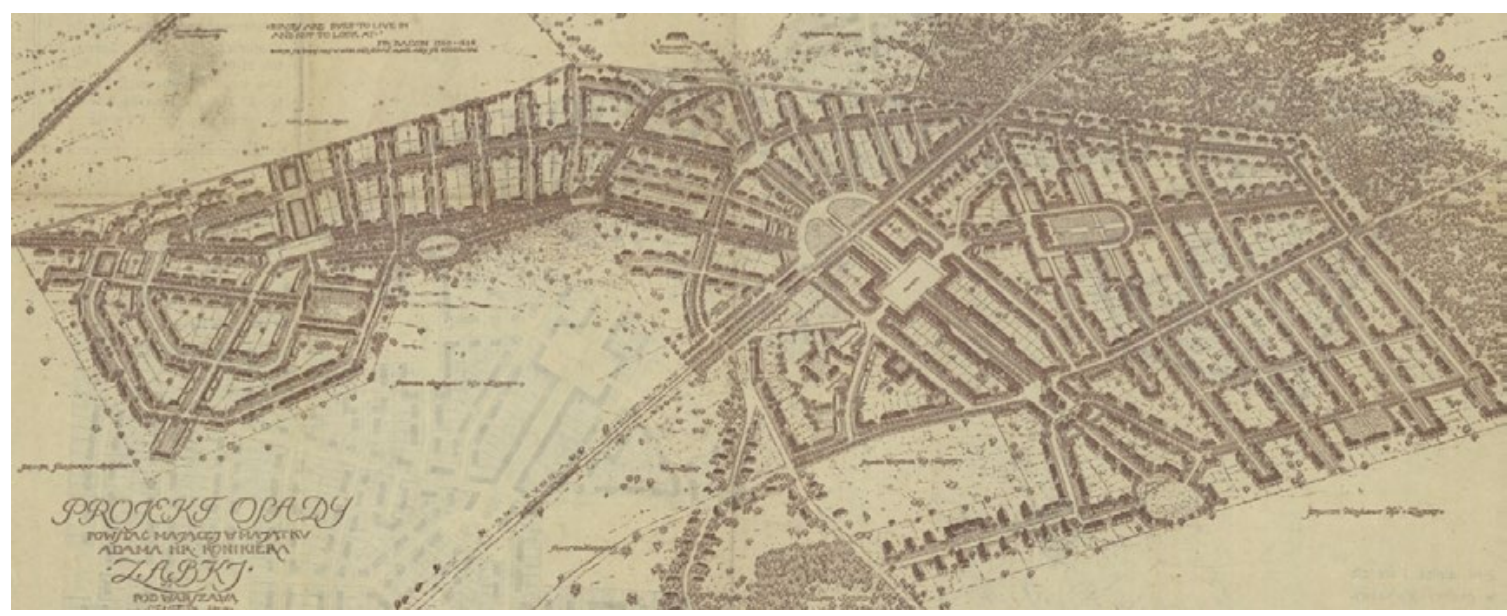

Ryc. 2. Projekt osady powstać mającej w majątku Adama hr. Ronikiera „Ząbki” pod Warszawą, autorstwa Tadeusza Tołwińskiego, 1912 r.

Design of settelment in Adam Ronikier "Ząbki" complex near Warsaw, designed by Tadeusz Tołwinski, 1912.

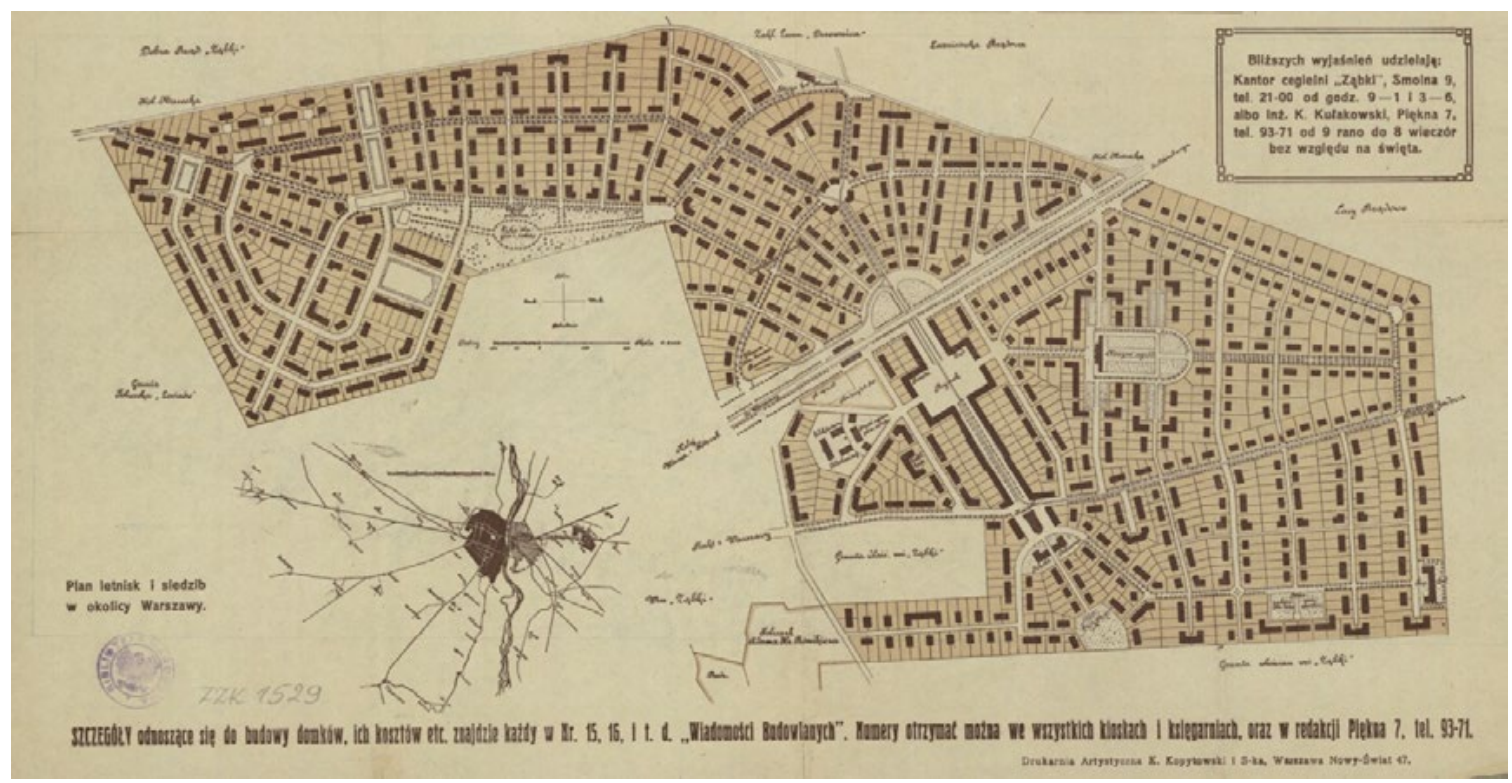

Ryc. 3. Plan parcelacyjny osady „Ząbki” pod Warszawą, autorstwa Tadeusza Tołwińskiego, 1912 r.

Plan of parcelation for the "Zabki" settlement near Warsaw, authored by Tadeusz Tołwiński, 1912. 
Ząbki miały być pierwszą wzorowo zaprojektowana osada miejska ${ }^{8}$, z przeznaczeniem na zamieszkanie całoroczne. Osada Ząbki oparta została na głównych zasadach miasta ogrodu Howarda. Stanowić miała samowystarczalne osiedle mieszkaniowe, z własną elektrownią, wodociągiem oraz strażą pożarną, skomunikowane z Warszawą za pomocą tramwaju elektrycznego łączącego Ząbki z rogatką radzymińską. Centrum założenia stanowić miał rynek wraz z najważniejszymi budynkami użyteczności publicznej takimi jak: poczta i sąd. Na osi rynku umieszczony został kościół, budynek szkoły oraz ochronki. W części wschodniej założenia umieszczono szpital.

Zwycięski projekt zakładał także odpowiednią hierarchizację dróg, przewidziano także bardzo duży odsetek terenów zieleni w postaci ogrodów publicznych, placów zabaw dla dzieci oraz ogrodów sportowych. Budynki mieszkalne (wolno stojące wille, bliźniaki i szeregowce), zaprojektowane zostały tak, aby fasady obiektów zwrócone były na wschód albo na zachód (Ryc. 2,3$)^{9}$.

Na tym tle nie dziwi fakt, że osada Wożuczyn, projektowana przez warszawskiego architekta Tadeusza Zielińskiego ${ }^{10}$, oparta została na głównych założeniach miast ogrodów powstających wówczas w Polsce i Europie. Przy czym cały układ został mocno zmodyfikowany i dostosowany do zastanych warunków i specyfiki projektowanego terenu. Artykuł ma za zadanie przedstawić główną ideę proponowaną przez T. Zielińskiego oraz to co pozostało z częściowo zrealizowanego i wielokrotnie modyfikowanego planu.

\section{Stan badań}

Osada Wożuczyn-Cukrownia nie doczekała się jeszcze całkowitego opracowania w przeciwieństwie do oddalonego zaledwie $5 \mathrm{~km}$ Wożuczyna.

Na temat cukrowni w Wożuczynie pisali między innymi E. Przesmycka (2008), B. Typek (2011) oraz B. Kwiatkowski (2012).

Założeniu ogrodowemu osady zostało poświęcone opracowanie E. Bończak-Kucharczyk Dokumentacja ewidencyjna założenia w Wożuczyn-Cukrowni z roku 1988 znajdująca się zbiorach Wojewódzkiego Urzędu Opieki nad Zabytkami w Zamościu oraz artykuł z odnalezionym planem osady (1922 r.) autorstwa B. Typek (2008).

\section{Kompozycja urbanistyczna osady Wożuczyn-Cukrownia}

Pierwszą cukrownią na Lubelszczyźnie była cukrowania w Poturzynie datowana na rok 1840 jednak bardzo duży rozwój cukrownictwa na obszarze Międzyrzecza datowany jest na pół wieku później bo na przełom XIX/XX w.

Już w roku 1913 ogólna liczba cukrowni na tym terenie szacowana była na 14 obiektów co dawało 25,9\% całej liczy cukrowni na terenie Królestwa Polskiego.

W połowie XIX wieku zauważalna była tendencja lokalizowania zakładów cukrowni w pobliżu istniejących folwarków, będących prywatną własnością.

Budynki cukrowni były bardzo dobrze skomunikowane z liniami kolejowymi część z nich posiadała także własną wąskotorową kolej (Nieledew, Klemensów, Garbów, Opole Lubelskie, Wożuczyn) ${ }^{11}$ co było elementem sprzyjającym dla nowo planowanych osad mieszkaniowych pracowników cukrowni.

Wyżej opisana sytuacja miała miejsce w osadzie Wożuczyn-Cukrownia położonej około $20 \mathrm{~km}$ od miasta Tomaszowa Lubelskiego oraz 5 km od wsi Wożuczyn (Ryc. 5).

Jej powstanie wiąże się z działalnością Tomasza Wydżgi - właściciela tych ziem² ${ }^{12}$, który na początku wieku XX wraz z udziałowcami założył spółkę Cukrowania Wożuczyn Spółka Akcyjna ${ }^{13}$.

8 Projekt osady powstać mającej w majątku Adama hr. Ronikiera „Ząbki” pod Warszawą, autorstwa Tadeusza Tołwińskiego, 1912 r.

9 A. Bohm, Planowanie przestrzenne dla ...., op. cit. , s. 127-129.

10 Plany osady Wożuczyn, oraz poszczególnych rysunków sekcyjnych opisanych w tekście podpisane są przez dwóch architektów: Tadeusza Zielińskiego oraz M. Bystydzieński.

11 B. Kwiatkowski, Folwarki Lubelszczyzny historia rozwoju i zabudowy, Politechnika Lubelska, Lublin 2012 , s. 104

12 Według Słownika geograficznego Królestwa Polskiego i innych krajów słowiańskich w 1884 roku folwark posiadał powierzchnię 1864 mórg gruntów ornych i ogrodów 902 mórg, łąk 168 mórg, pastwisk 16 mórg zaś lasu 540 mórg za: Słownik geograficzny Królestwa Polskiego i innych krajów stowiańskich,wydany pod redakcją Bronislawa Chlebowskiego TXV, druk "wieku” Nowy Świat nr 61 , Warszawa, 1900 s. 15.

13 B. Typek, Walory osady Cukrowni Wożuczyn, Zamojski kwartalnik kulturalny, Nr. 2, 2008, s. 39-43. 


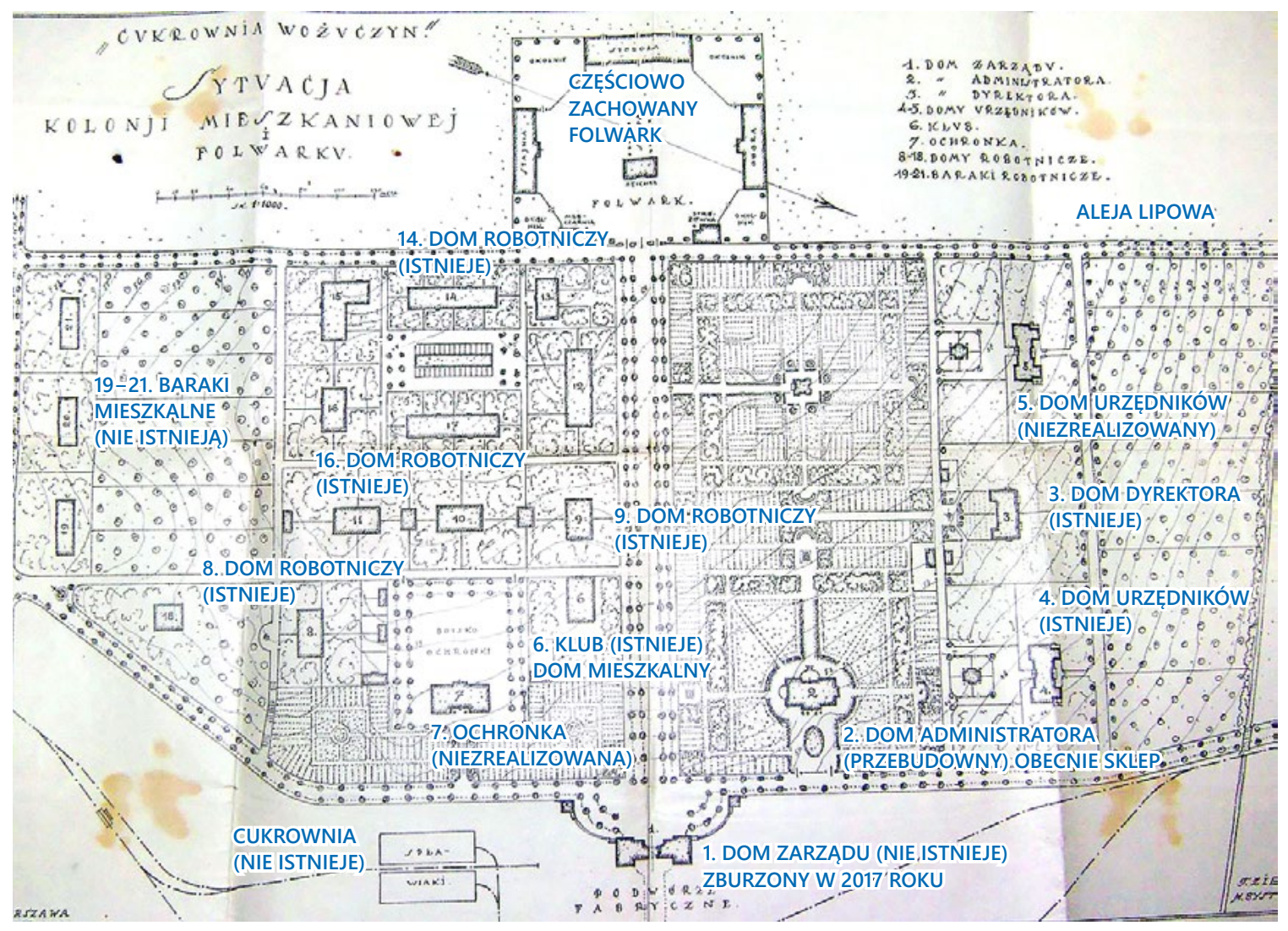

Ryc. 4. Plan osady Wożuczyn z 1922 roku wraz z opisem (archiwum B. Typek, oprac. na podstawie artykułu Walory osady Wożuczyn-Cukrowni oraz wizji lokalnej)

Plan of Wozuczyn settlement from 1922 (archive owned by B. Typek)

Osada rozplanowana została na osi wschód-zachód pomiędzy folwarkiem Tomasza Wydżgi, a domem zarządu cukrowni (Ryc. 6a). W części północnej założenia zlokalizowane były reprezentacyjne budynki z domem administratora otoczonym parkiem, dwoma domami urzędników i budynkiem dyrektora cukrowni usytuowanym pomiędzy budynkami urzędniczymi graniczącymi z sadem (Ryc. 4).

Budynek administratora poprzedzony był podjazdem z owalnym gazonem. Od budynku usytuowanego na owalnym placu odchodziły promieniste spacerowe ścieżki. Na głównej osi założenia usytuowany był element ozdobny o półkolistym kształcie w formie eksedry. W północnej części zlokalizowano kwaterowe, ogrody użytkowe z centralnie umieszczonym, wygrodzonym budynkiem gospodarczym otoczonym ośmioma drzewami.

W części południowo-wschodniej osady przewidziano budynek ochronki, który niestety nie został zrealizowany. Obiekt ten poprzedzały ogrody spacerowe i użytkowe, zaś za budynkiem usytuowane było boisko do gier otoczone dwoma szpalerami drzew.

Część południowa osady została przeznaczona odpowiednio na budynki mieszkalne - domy robotnicze sytuowane w ogrodach oraz baraki oddzielone od całości założenia sadem.

Większość budynków wzniesiona została w latach 1922-1939. W stosunku do pierwotnego założenia z 21 zaplanowanych i zrealizowanych budynków do chwili obecnej przetrwało $8^{14}$ zaś z budynków gospodarczych siedem. Pierwotna powierzchnia osady wynosiła 27,5 ha. Po wojnie Wożuczyn ulegał dalszym przekształceniom. W przestrzeni osady pojawiły się nowe budynki gospodarcze, wybudowano hotel robotniczy oraz bloki mieszkaniowe nie korespondujące z otoczeniem. Zabytkowa zieleń ulegała degradacji, nowe nasadzenia nie kontynuowały idei planu Tadeusza Zielińskiego. Park przy domu administratora (potem szkoły i przedszkola) 
zatracił swój pierwotny układ ${ }^{15}$. Alejki parku zostały wyasfaltowane, pierwotny układ kompozycji stał się prawie niemożliwy do oczytania. W miejscu dawnego ogrodu ozdobnego pojawiło się wyasfaltowane boisko, które rozbiło historyczną kompozycję ogrodu (Ryc. 6b).

W tabeli przedstawiono porównanie założenia idei miasta ogrodu E. Howarda w stosunku do planu i założeń w zakresie kształtowania osady Tadeusza Zielińskiego z roku 1922.

Tabela 1. Tabela porównawcza przedstawiająca zestawienie projektowanych rozwiązań w Wożuczyn-Cukrowni w stosunku do głównych idei miasta ogrodu E. Howarda.

Comparative table presenting a list of designed solutions in Wozuczyn settlement related to the main ideas of the garden by E. Howard

\begin{tabular}{|c|c|c|}
\hline $\begin{array}{c}\text { Cechy } \\
\text { charakterystyczne }\end{array}$ & $\begin{array}{l}\text { Miasto ogród Howarda - } \\
\text { założenia ideowe }\end{array}$ & Osada Wożuczyn-Cukrownia \\
\hline Układ/funkcja & $\begin{array}{l}\text { Miasto centryczne } \\
\text { o promienistym układzie ulic } \\
\text { / miasto samowystarczalne } \\
\text { o funkcji satelitarnej do dużego } \\
\text { ośrodka / miasto budowane } \\
\text { na surowym korzeniu / } \\
\text { Zróżnicowanie funkcji obiektów }\end{array}$ & $\begin{array}{l}\text { Osada przy cukrowni, układ pasmowy oparty } \\
\text { na ortogonalnej siatce i dwóch głównych } \\
\text { osiach kompozycyjnych wschód-zachód, } \\
\text { północ-południe / osada granicząca } \\
\text { z folwarkiem właściciela ziemskiego wpisująca } \\
\text { się w zastany kontekst / zróżnicowana typologia } \\
\text { budynków mieszkalnych, gospodarczych oraz } \\
\text { budynków użyteczności publicznej w postaci } \\
\text { klubu i ochronki (nigdy nie powstała) }\end{array}$ \\
\hline Skala & $\begin{array}{l}\text { Mała skala / maksymalna } \\
\text { liczba mieszkańców } \\
32000 \text { a powierzchnia } \\
400 \text { ha / wznoszone przez } \\
\text { niewielkie kooperatywy }\end{array}$ & $\begin{array}{c}\text { Mała skala, powierzchnia osady około } 29 \text { ha / } \\
\text { wznoszone przez Tomasza Wydżgę, Stanisława } \\
\text { Kowerskiego, Aleksandra Szeptyckiego }\end{array}$ \\
\hline $\begin{array}{l}\text { Przestrzenie } \\
\text { publiczne }\end{array}$ & $\begin{array}{c}\text { Hierarchia wnętrz } \\
\text { architektonicznych, czytelne } \\
\text { kształtowanie przestrzeni, } \\
\text { różnorodność form zabudowy, } \\
\text { charakterystyczny detal } \\
\text { urbanistyczny oraz zastosowany } \\
\text { materiał budowlany kreujący } \\
\text { tożsamość miejsca }\end{array}$ & $\begin{array}{l}\text { Brak wspólnych przestrzeni publicznych, } \\
\text { różnorodność form zabudowy w zależności } \\
\text { od pełnionej funkcji: dom dyrektora } \\
\text { cukrowni, dom urzędników, dom } \\
\text { administratora, domy robotnicze oraz } \\
\text { budynki gospodarcze / charakterystyczny } \\
\text { detal architektoniczny w formie drewnianych } \\
\text { kolumn i zastosowanego materiału dachówki } \\
\text { ceramicznej i dachów namiotowych } \\
\text { przekrywających budynki gospodarcze }\end{array}$ \\
\hline Zieleń & $\begin{array}{c}\text { Zieleń ujęta w założeniu } \\
\text { jako czynnik miastotwórczy, } \\
\text { zróżnicowanie form zieleni (aleje, } \\
\text { skwery, parki miejskie, przestrzenie } \\
\text { do gier i zabaw, ogrody użytkowe, } \\
\text { sady), nadanie im funkcji }\end{array}$ & $\begin{array}{l}\text { Zróżnicowanie form zieleni, projektant } \\
\text { przewidział dwa sady, ogrody ozdobne } \\
\text { i użytkowe, zaprojektowane były podwójne } \\
\text { aleje na osi wschód-zachód oraz pojedyncze na } \\
\text { osi północ-południe, w projekcie przewidziane } \\
\text { było także boisko sportowe dla budynku } \\
\text { ochronki - jednak nigdy nie powstało }\end{array}$ \\
\hline Komur & $\begin{array}{l}\text { Miasto dobrze skomunikowane } \\
\text { przez kolej }\end{array}$ & $\begin{array}{l}\text { Osada wzniesiona wzdłuż linii } \\
\text { kolejki wąskotorowej }\end{array}$ \\
\hline
\end{tabular}

Tabela opracowana przez autora, 2017 


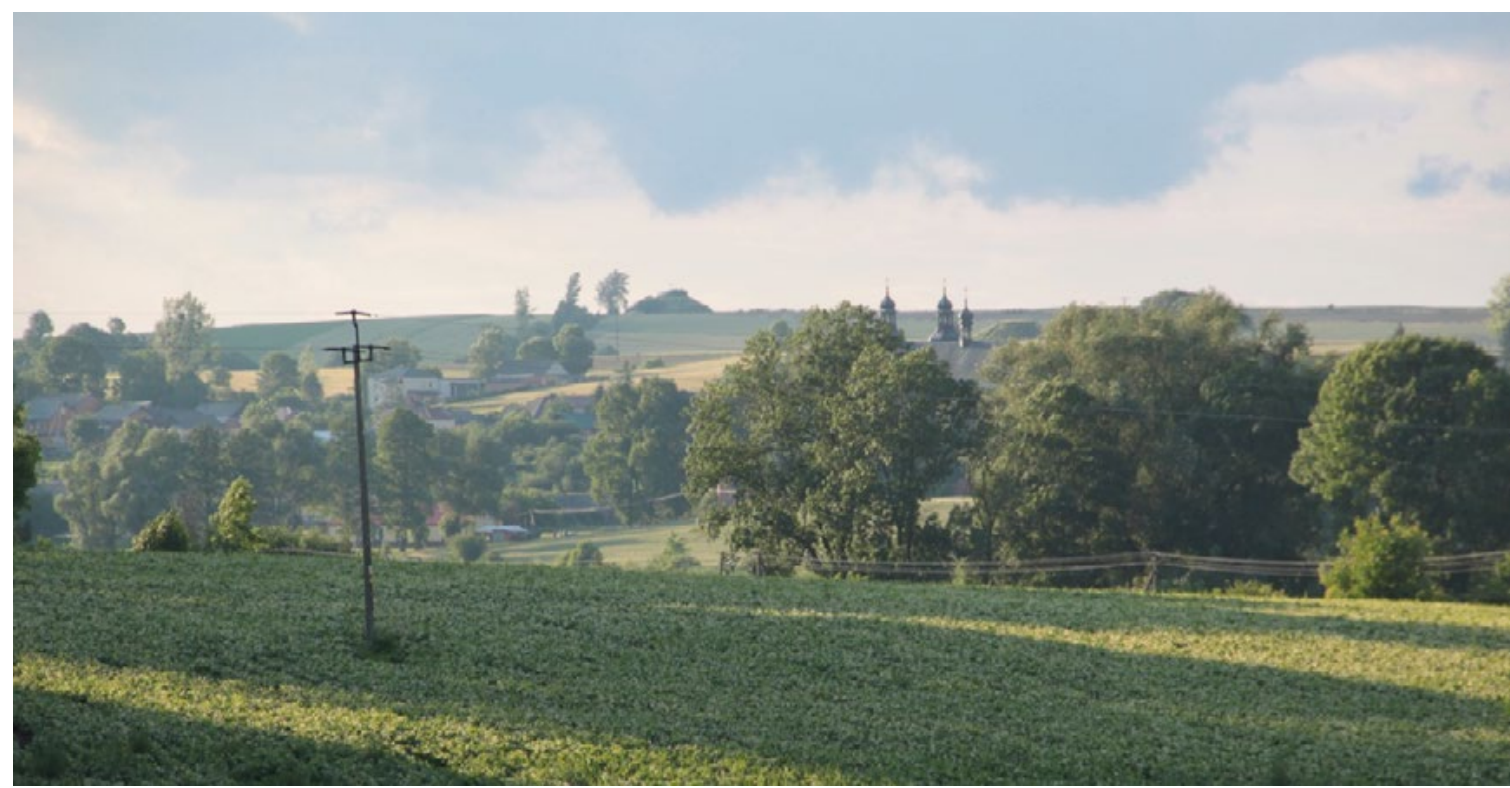

Ryc. 5. Widok na panoramę Wożuczyna, w tle widoczne wieże kościoła parafialnego.

View of the panorama of Wozuczyn, in the background the towers of the parish church.
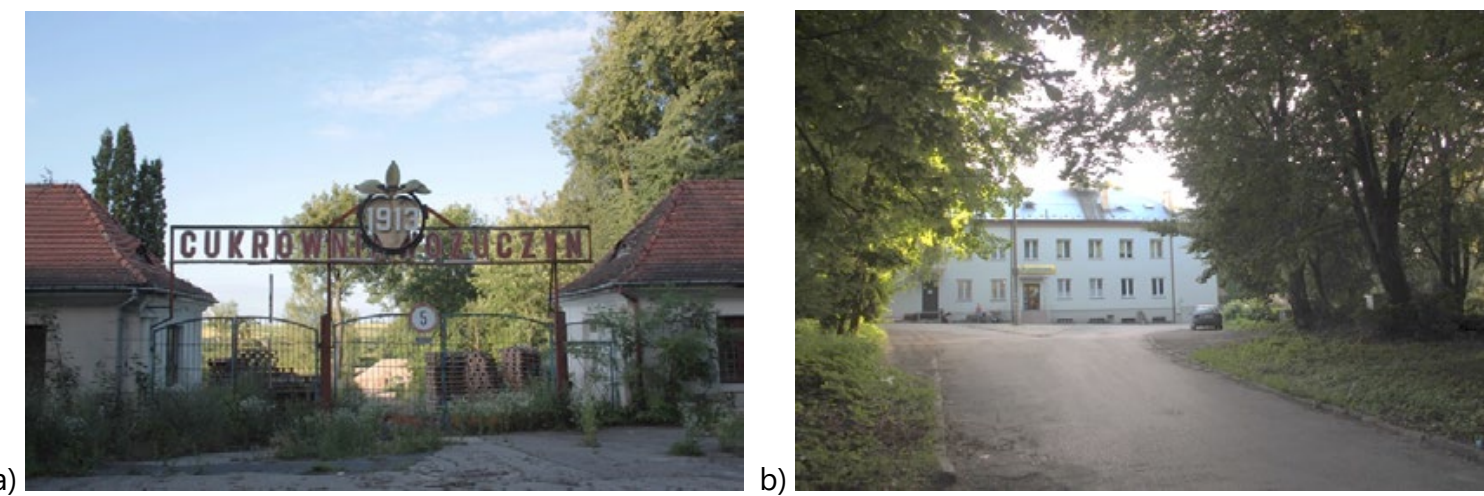

Ryc. 6. a) Brama prowadząca do cukrowni, b) budynek administratora cukrowni wraz z otaczającym parkiem Tatarów - Jerzym i Alicją Romaszkan, z synem Janem Gawłem. W tle fragment elewacji zachodniej domu Romaszkanów. Fot. z lat 30. XX w. Źródło: [Jasiński, s. 585].

a) Gate to sugar plant, b) sugar refinery administrator building with the surrounding park

\section{Kompozycja zieleni w osadzie Wożuczyn-Cukrowni}

Projektując osadę Wożuczyn-Cukrownia Tadeusz Zieliński musiał wziąć pod uwagę istniejący folwark wraz z aleją lipową łączącą go z pobliskimi stawami. Do dzisiaj aleja ta czytelna jest w układzie osady wyznaczając jej granicę od strony północnej (Ryc. 7). Drzewa tam posadzone datowane są na połowę wieku XIX.

Podobnie do chwili obecnej w przestrzeni osady czytelne są poszczególne szpalery starych lip, brzóz czy klonów stanowiących niegdyś aleje czy elementy wygradzające poszczególne przestrzenie. W planie Tadeusza Zielińskiego przewidziane było bowiem różnorodne formy zieleni takie jak: sady, ogrody ozdobne i użytkowe czy boisko sportowe nigdy niezrealizowane a przeznaczone dla budynku ochronki. Architekt zaprojektował także podwójne aleje na osi wschód-zachód oraz pojedyncze na osi północ-południe. 


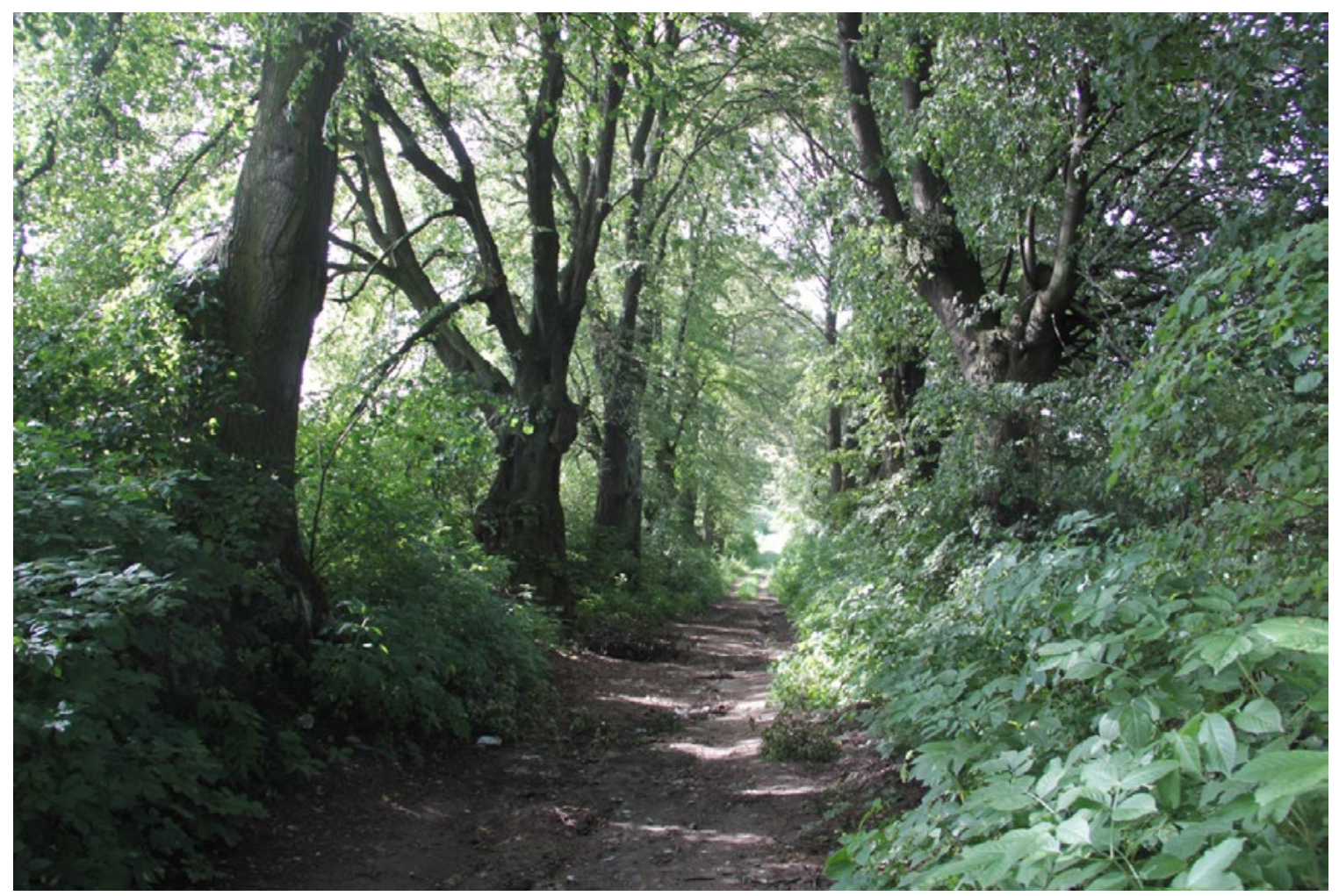

Ryc. 7. Stara aleja lipowa, fot K. Boguszewska (lipiec 2017)

The old linden alley, photo by K. Boguszewska (June 2017)

W roku 1922 rozpoczęto realizację parku wokół domu administratora cukrowni. Za materiał roślinny odpowiedzialni byli ogrodnicy z pobliskiego Wożuczyna. Aleje obsadzano brzozami, żywotnikami, zaś we wnętrzach ogrodowych sadzono gatunki takie jak: świerk, kasztanowce, robinie, klony oraz lipy. Krzewy reprezentowane były przez nasadzenia lilaków i jaśminowców. Przed wybuchem drugiej wojny światowej zrealizowano cały układ przestrzenny osady oraz sad zlokalizowany w północnej części założenia ${ }^{16}$. Pod koniec lat 90-tych XX wieku na terenie osady występowało 63 gatunki drzew i krzewów. Zaewidencjonowano także wówczas pojedyncze nasadzenia soliterowe gatunków takich jak: jawor czy lipa szerokolistna ${ }^{17}$.

\section{Kompozycja ogrodu przy domu urzędników}

Dom Urzędników zlokalizowany został w północno-wschodnim narożniku osady. Jego realizacja przypada na lata 1922-1939, analogiczny budynek wraz z otoczeniem przewidziany został w części północno-zachodniej jednak nigdy nie doszło do jego realizacji, a w chwili obecnej znajduje się tam Ośrodek Kultury wzniesiony w latach 90-tych. Budynek „Domu Urzędników” wybudowany został w stylu XX wiecznego historyzmu nawiązującego do architektury polskiego dworu (Ryc. 10). 


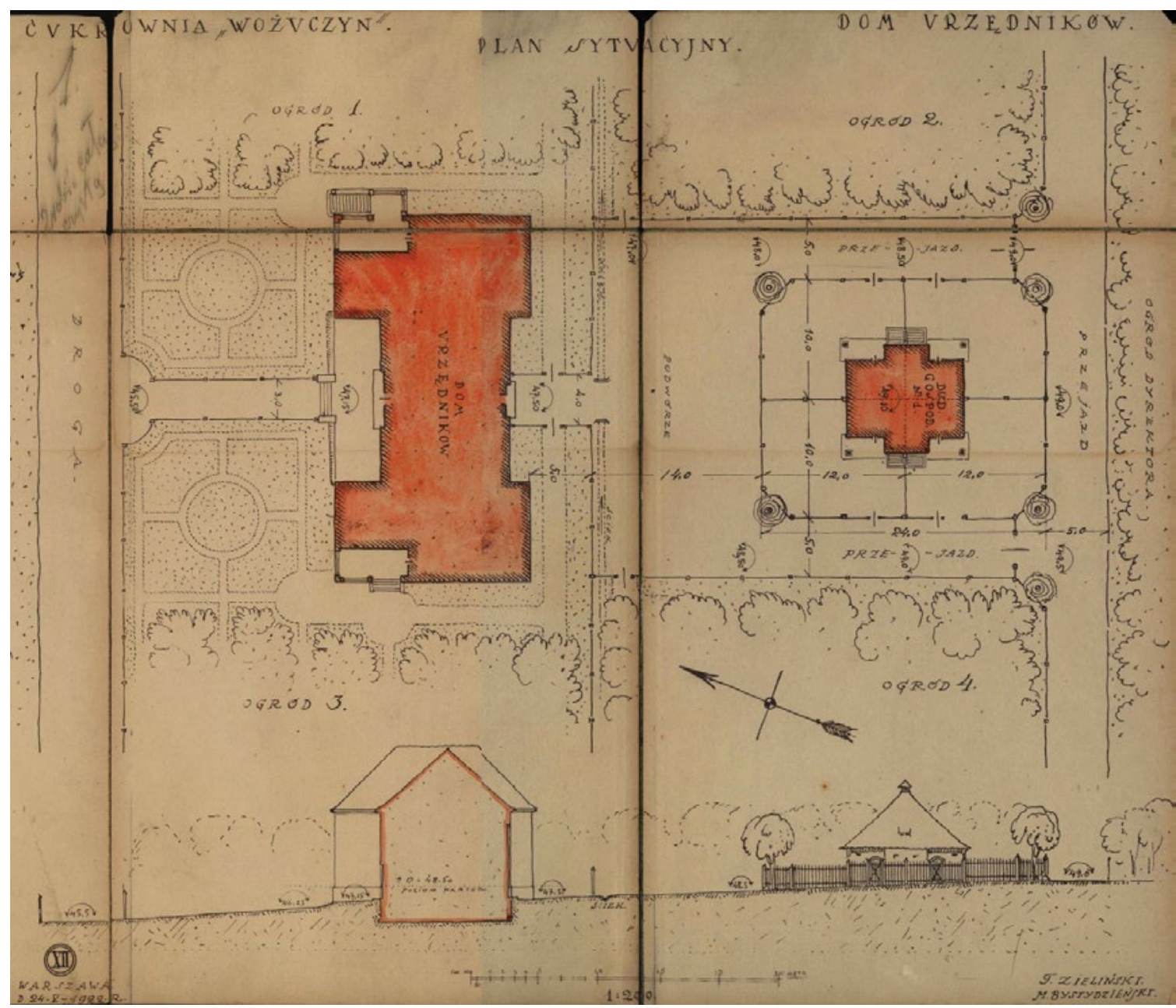

Ryc. 8. Plan sytuacyjny rozplanowania działki przy domie urzędników wraz z przekrojem (APL, UWL, s. 2440)

Plan of the surrounding around House of officials with section (APL, UWL, s.2440)

Działka na której wzniesiono budynek mieszkalny wraz z okólnikiem gospodarczym była w całości ogrodzona - drewnianymi sztachetami, prawdopodobnie takimi samymi jak budynek gospodarczy usytuowany na zapleczu od strony południowej działki, który posiadał dodatkowe wygrodzenie (Ryc. 8).

Przed budynkiem zlokalizowany był reprezentacyjny ogród w formie symetrycznych gazonów o charakterze parterów na których zaprojektowano ścieżki spacerowe powiązane ze wszystkim wejściami do obiektu i aleją obiegającą budynek.

Główna ścieżka prowadząca do budynku miała trzy metry szerokości, a na tarasie poprzedzonym czterema stopniami usytuowanym przy elewacji frontowej zaprojektowane były dwie symetrycznie ustawione ławki widoczne w rysunku elewacji głównej budynku (Ryc. 9). Posiadały one stylizowaną, architektoniczną formę wzorowaną na elementach małej architektury przełomu XIX/XX wieku stosowaną w krajobrazowych parkach.

Na podwórzu zaplanowane były dwa pięciometrowe przejazdy usytuowane symetrycznie od strony południowej. Otaczały one wygrodzony teren $20 \times 24$ metry na którym usytuowany był budynek gospodarczy z czterospadowym, namiotowym dachem krytym dachówką ceramiczną. Budynek gospodarczy wzniesiony był w konstrukcji drewnianej z charakterystycznym detalem drewnianych kolumn wspierających podcienia, gdzie nawierzchnię stanowiły kocie łby (Ryc. 11a, b, 12a, b).

W narożnikach budynku gospodarczego już za drewnianym parkanem zaprojektowane były cztery niewielkie drzewa liściaste. Podobnie jak przy dwóch bramach wjazdowych prowadzących na teren posesji od strony 
południowej. Zarówno od strony wschodniej i zachodniej zaplanowane były nasadzenia krzewów wydzielających przestrzeń działki od sąsiadujących od strony wschodniej i zachodniej ogrodów (Ryc. 8).

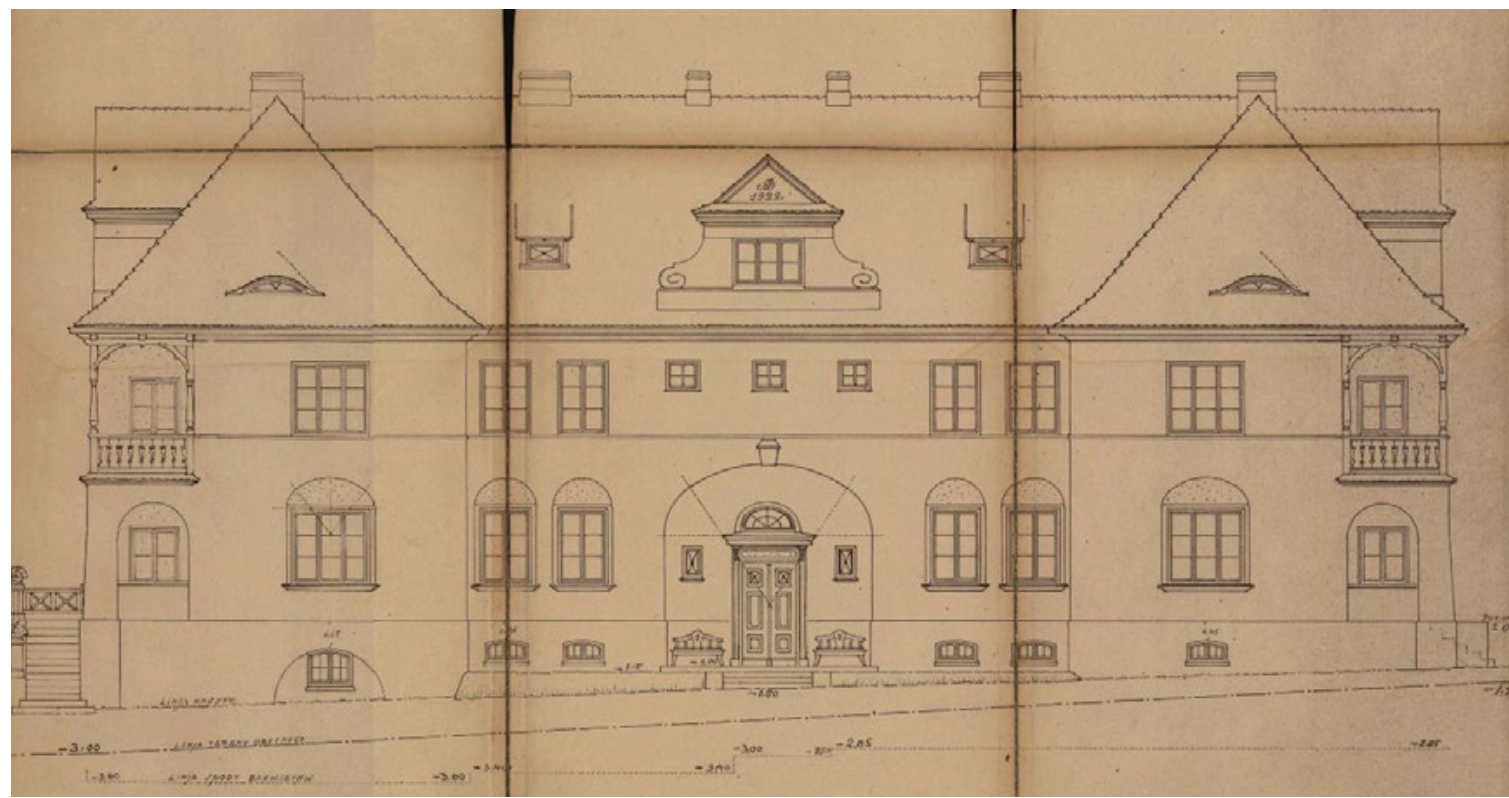

Ryc. 9. Dom Urzędników - elewacja frontowa (APL, UWL, s. 2440)

House of officials - main facade (APL, UWL, s. 2440)

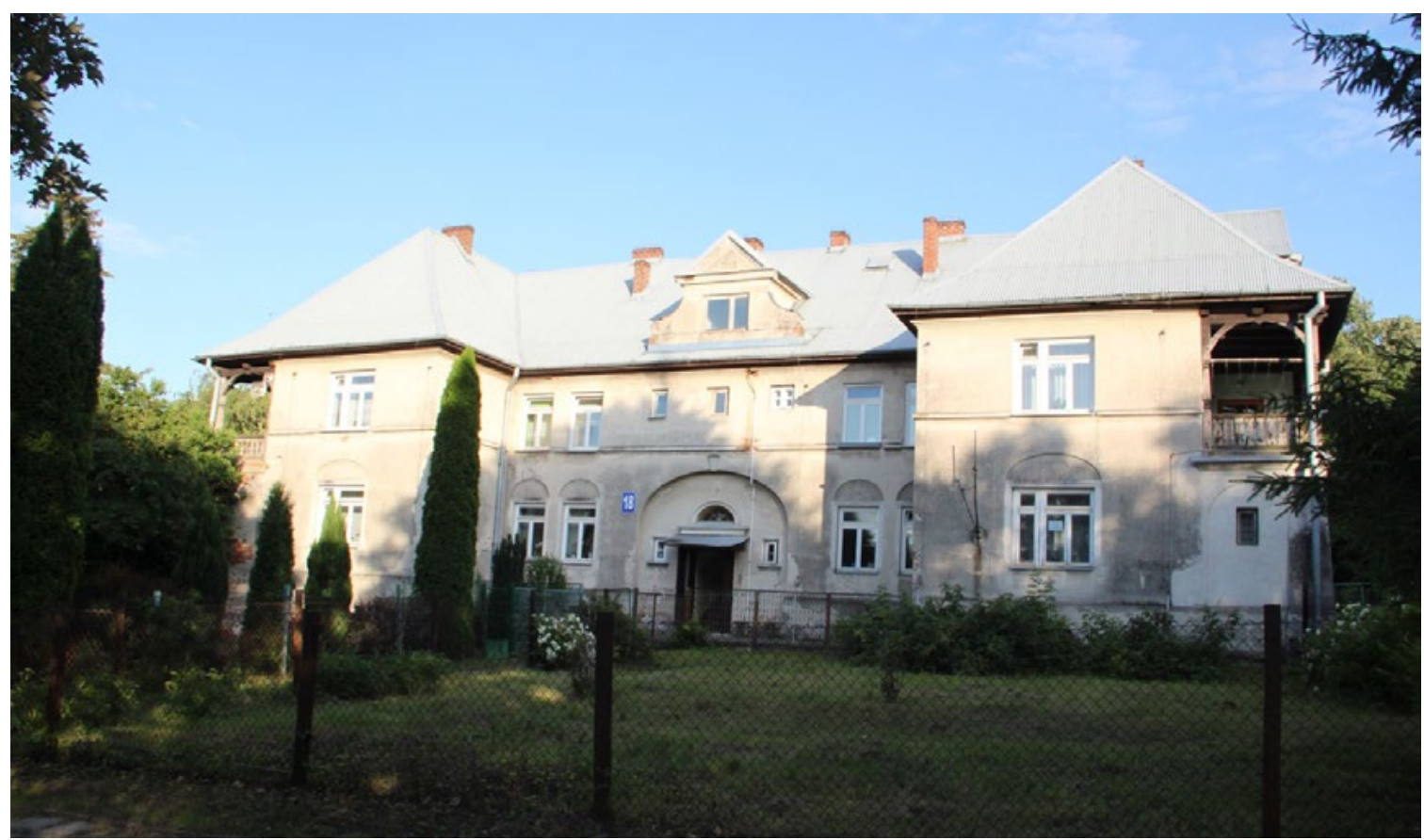

Ryc. 10. Dom Urzędników - stan obecny, fot K. Boguszewska, lipiec 2017

House of officials - state of preservation, photo by K. Boguszewska, June 2017 
a)
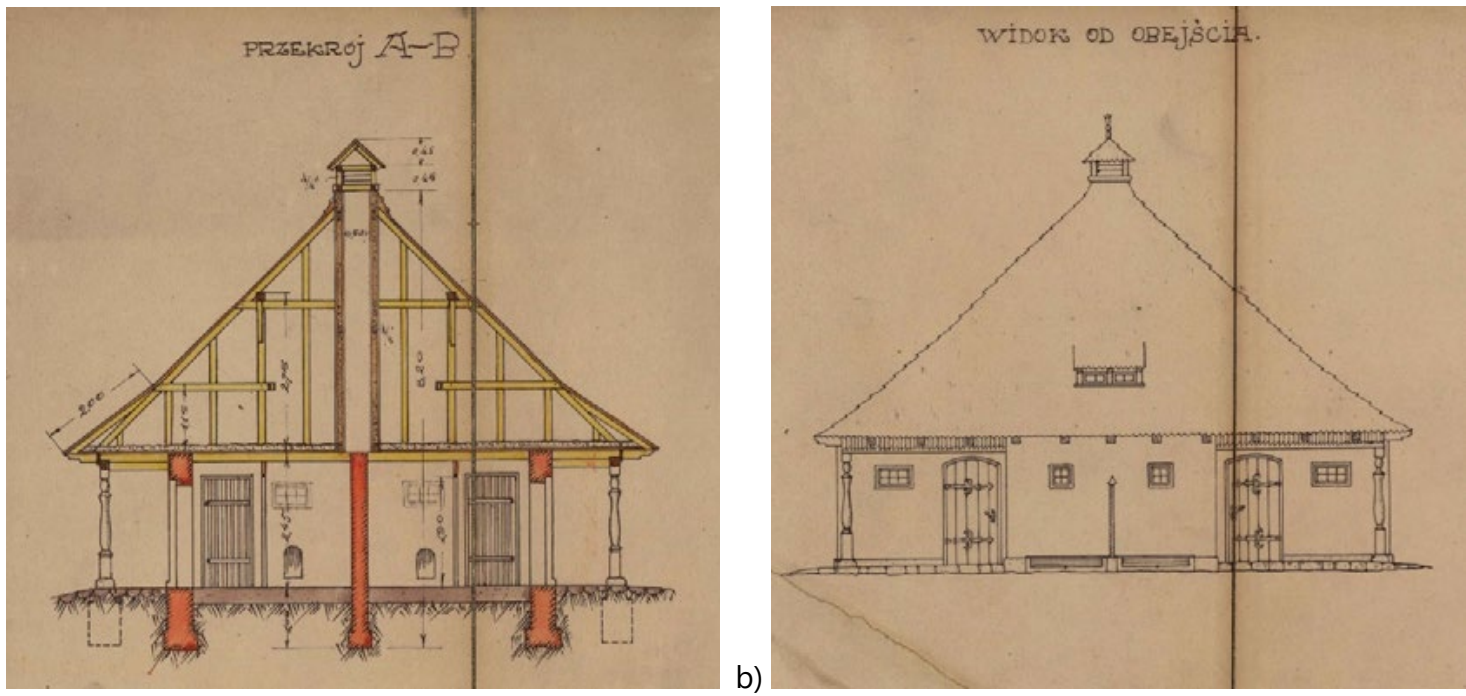

Ryc. 11. Budynek gospodarczy, a - przekrój, b - elewacja budynku od strony obejścia (APL, UWL, s. 2441) Outbuilding, a - section, b - view of facade from courtyard (APL, UWL, s. 2441)

a)
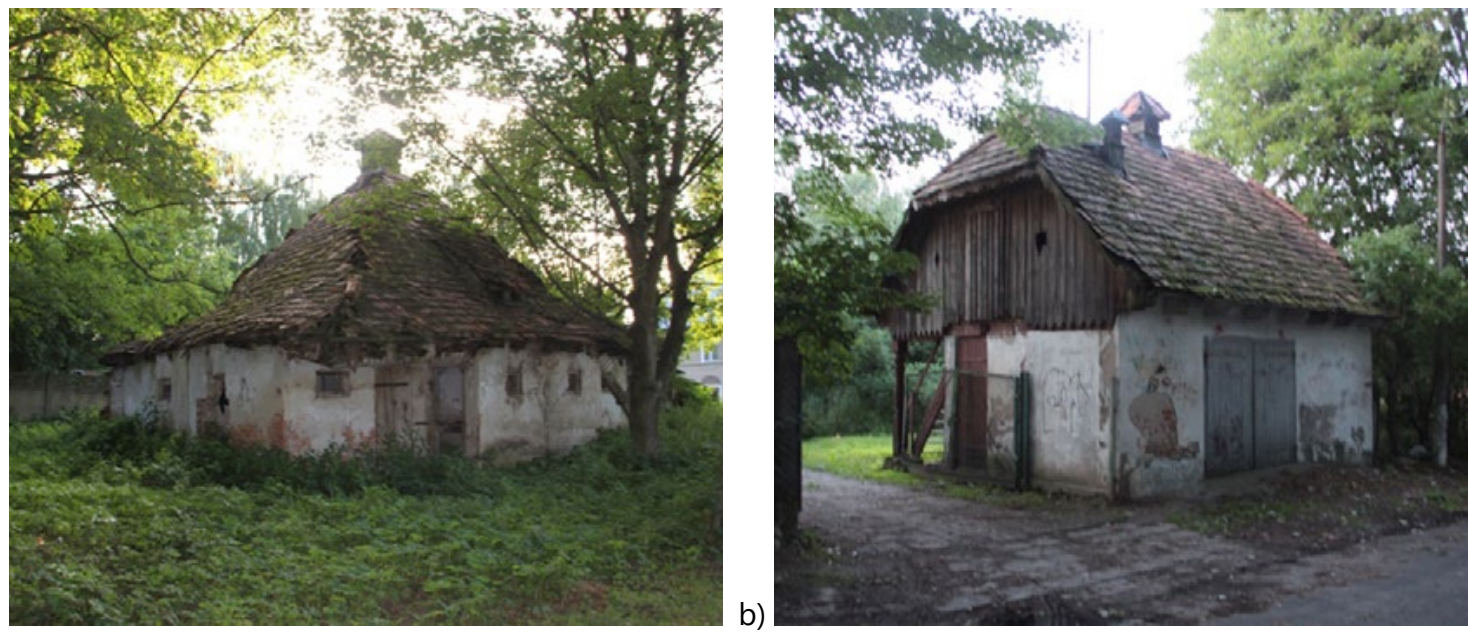

Ryc. 12. Budynki gospodarcze w Wożuczynie-Cukrowni, stan obecny, fot. K. Boguszewska, lipiec 2017

Outbuildings in Wozuczyn-Cukrownia, state of preservation, photo by K. Boguszewska, june 2017

\section{Podsumowanie}

Osada Wożuczyn-Cukrownia pełni w chwili obecnej jedynie funkcję mieszkalną. Kiedy w roku 2008 B. Typek pisała o kolonii stawiała tezę, że osadę można zrewitalizować poprzez wprowadzenie funkcji rekreacyjno-turystycznej ${ }^{18}$.

Niestety, we wrześniu 2017 roku wszystkie zabudowania będące pozostałością dawnej cukrowni zostały wyburzone. Mieszkańcy zawiązali komitet - Stowarzyszenie miłośników Wożuczyna i okolic, którego celem było uratowanie historycznej bramy wjazdowy i umieszczenie jej z powrotem w przestrzeni osady (Ryc. 6a).

Tym samym zniszczone zostało dziedzictwo, które niegdyś było przyczynkiem do powstania całej kolonii mieszkaniowej. Dalsze zmiany w postaci parcelacji działek i przekształceń budynków nie wpisują się w pierwotny plan osady, zmieniając tym samym bezpowrotnie jej charakter. 
Brak pieniędzy na ochronę i konserwację powoduje, że historyczna architektura znika z krajobrazu ziemi tomaszowskiej. Stan zachowania drewnianych okólników, niegdyś jednego z wielu elementów tożsamości tej osady jest taki, że nadają się one jedynie do odbudowania. Podobnie ma się sprawa z zabytkowym parkiem, wymaga on bowiem nakładów finansowych oraz profesjonalnej pielęgnacji. Jedynym rozwiązaniem tej trudnej sytuacji jest mądrze przeprowadzony proces rewitalizacji tej miejscowości.

\section{Bibliografia}

[1] Bohm A., Planowanie przestrzenne dla architektów krajobrazu o czynniku kompozycji, Kraków 2006

[2] Dobrzański W., Krótki zarys prac delegacyi do sprawy miast ogrodów przy Warszawskim Towarzystwie Higienicznym ze sprawozdaniem z wystawy miast ogrodów, Druk synów. S, Niemiry,

[3] Warszawa 1912,

[4] Dobrzański W., Zdrowie publiczne a idea miast ogrodów, Druk synów. S, Niemiry

[5] Warszawa 1911,

[6] Dobrzański W., Postępy idei miast ogrodów w Anglii i u nas, Druk synów. S, Niemiry

[7] Warszawa 1914,

[8] Dobrzański W., Istota i rozwój idei Howarda miasto ogród, Druk Rubiszowskiego i Wrotnowskiego, Czckiego 3/5, Warszawa 1917,

[9] Howard H., Garden city of tomorrow, London, Swan Sonnenschein \& Co., Ltd., 1902, s. 21-22.

[10] Kwiatkowski B., Folwarki Lubelszczyzny historia rozwoju i zabudowy, Politechnika Lubelska, Lublin 2012

[11] Przesmycka E., Idea osiedli mieszkaniowych wXX wieku [w:] Stalowa Wola europejskie miasto modernistyczne,

[12] Muzeum Regionalne w Stalowej Woli, Stalowa Wola, 2014, s. 12.

[13] Przesmycka E. Lubelszczyzna. Wielokulturowość osadnictwa, budownictwa i architektury, Lublin 2008.

[14] Stownik geograficzny Królestwa Polskiego i innych krajów słowiańskich, wydany pod redakcją Bronisława Chlebowskiego TXV, Druk "wieku" Nowy Świat nr 61, Warszawa, 1900

[15] Typek B., Cukrownia Wożuczyn, "Zamojski Kwartalnik Kulturalny", Nr 1/2011, s. 32-39.

[16] Typek B., Walory osady Cukrowni Wożuczyn, Zamojski kwartalnik kulturalny, Nr 2, 2008

\section{Materiały archiwalne}

[17] Cukrownia Wożuczyn - sytuacja kolonji mieszkaniowej i folwarku, Warszawa 15.06.1922 r. (Zbiory prywatne B. Typek)

[18] APL, UWL, Projekt budynku gospodarczego Kolonii Urzędniczej Spótki Akc. Cukrowni w Wożuczynie, pow. Tomaszowski, s. 2441

[19] APL, UWL, Projekt domu mieszkalnego Kolonii Urzędniczej Spótki Akc. Cukrowni w Wożuczynie, pow. Tomaszowski, s. 2440

\section{Źródła internetowe}

[20] Bończak-Kucharczyk E., Oleksicki A, Kucharczyk K., Oleksicki Jerzy, Żukowski J., Dokumentacja ewidencyjna zatożenia ogrodowego przy cukrowni w Wożuczynie, Zamość 1988, (archiwum WUOZ Zamość) dostęp internat: http://www.testowy.minigo.pl/index.php/article/show/id/427grudzień 2017). 


\section{Traces of the garden-city idea on the example of Wozuczyn-Cukrownia}

Summary: At the beginning of the $20^{\text {th }}$ century, the idea of garden city (created by Ebenezer Howard 1898) gained the status of an international trend. It was not only in the urban dimension but also in the social too. The idea of this type of towns and village planning was transplanted to Poland in 1908. It was the time when W. Dobrzyński became acquainted with the main assumptions of the garden cities idea, which was presented during the International Congress of Hygiene and Demography in Berlin. On the wave of the popularity of Howard's ideas individual associations have been funded such as: city garden Mlociny (1913), Sokolniki (1931), Podkowa Lesna (1933) and Okęcie (1929).

Against this background, it is not surprising that Wozuczyn, which was designed in the early $20^{\text {th }}$ century by the Warsaw architect Tadeusz Zieliński, was maintained according to the main principles of shaping the city's gardens. The aim of the article is to present the state of preservation of the garden complex in Wozuczyn-Cukrownia in the light of the archival documentation.

Keywords: garden city, Tadeusz Zieliński, Wożuczyn-Cukrownia 